\title{
Regional Housing Market Conditions in Spain
}

\author{
Citation for published version (APA):
}

Galesi, A., Mata, N., Rey, D., Schmitz, S., \& Schuffels, J. (2020). Regional Housing Market Conditions in Spain. Maastricht University, Graduate School of Business and Economics. GSBE Research Memoranda No. 029 https://doi.org/10.26481/umagsb.2020029

Document status and date:

Published: 29/10/2020

DOI:

10.26481/umagsb.2020029

Document Version:

Publisher's PDF, also known as Version of record

\section{Please check the document version of this publication:}

- A submitted manuscript is the version of the article upon submission and before peer-review. There can be important differences between the submitted version and the official published version of record.

People interested in the research are advised to contact the author for the final version of the publication, or visit the DOI to the publisher's website.

- The final author version and the galley proof are versions of the publication after peer review.

- The final published version features the final layout of the paper including the volume, issue and page numbers.

Link to publication

\footnotetext{
General rights rights.

- You may freely distribute the URL identifying the publication in the public portal. please follow below link for the End User Agreement:

www.umlib.nl/taverne-license

Take down policy

If you believe that this document breaches copyright please contact us at:

repository@maastrichtuniversity.nl

providing details and we will investigate your claim.
}

Copyright and moral rights for the publications made accessible in the public portal are retained by the authors and/or other copyright owners and it is a condition of accessing publications that users recognise and abide by the legal requirements associated with these

- Users may download and print one copy of any publication from the public portal for the purpose of private study or research.

- You may not further distribute the material or use it for any profit-making activity or commercial gain

If the publication is distributed under the terms of Article $25 \mathrm{fa}$ of the Dutch Copyright Act, indicated by the "Taverne" license above, 


\section{Maastricht University}

Alessandro Galesi, Nuria Mata, David Rey, Sebastian Schmitz, Johannes Schuffels

\section{Regional Housing Market} Conditions in Spain

RM/20/029

ISSN: $2666-8807$

\section{GSBE}

Maastricht University School of Business and Economics

Graduate School of Business and Economics

\section{P.O Box 616}

NL-6200 MD Maastricht

The Netherlands 


\title{
Regional Housing Market Conditions in Spain*
}

\author{
Alessandro Galesi ${ }^{1}$, Nuria Mata $^{2}$, David Rey ${ }^{1}$, Sebastian Schmitz ${ }^{2}$, and \\ Johannes Schuffels ${ }^{3}$ \\ ${ }_{1}$ idealista \\ ${ }^{2}$ European Commission \\ ${ }^{3}$ School of Business and Economics, Maastricht University
}

October 2020

\begin{abstract}
Selling homes is not easy. Home sellers usually need to apply a price discount to swiftly close a deal, and more so when housing market activity is low. Using detailed data on home listings and transactions in Spain, we provide unique estimates of the price discount across regional submarkets and time. We document that the price discount is strongly countercylical, as it increases with declining market conditions, and viceversa during upturns. Despite substantial heterogeneity, regional price discounts are synchronized and a single common factor can account for about sixty percent of their variation, thus suggesting the existence of a national housing cycle. Finally, we document that the main factors linked to changes in the price discount are developments in income, population, and interest rates, which are jointly able to explain the bulk of variation in housing market liquidity across regions and time. Besides providing a formal test of the performance of the price spread in gauging housing market liquidity, this study conveys practical information to real estate market participants, policymakers, and financial institutions for which assessing conditions in Spanish housing markets is a central task.
\end{abstract}

JEL Codes: R20, R30, R32

Keywords: Housing market, Asking price, Price discount, Market tightness

*Email: agalesi@idealista.com (Alessandro Galesi), Nuria.MATA-GARCIA@ec.europa.eu (Nuria Mata), drey@idealista.com (David Rey), Sebastian.SCHMITZ@ec.europa.eu (Sebastian Schmitz), j.schuffels@maastrichtuniversity.nl (Johannes Schuffels). We thank without implicating Pelayo Arbués, Daniel Del Pozo, Pilar Jimenez, Itsaso Mediavilla, Daniel Pardo, Stefan Zeugner for helpful support, discussions and suggestions. Disclaimer: The views expressed herein are those of the authors and not necessarily reflect those of the European Commission. 


\section{Introduction}

In residential property markets, sellers generally advertise their homes with an asking price, wait for offers of potential buyers, and eventually sell the property or withdraw the listing. ${ }^{1}$ Setting the right asking price is the crucial decision which the seller has to make, as pricing the house too high reduces the pool of potentially interested buyers and increases marketing time. If the house has remained unsold after a certain amount of time, the seller may decide to adjust the asking price downwards in order to close a deal with a potential buyer. Eventually, houses typically sell with a price discount, which averages 4 percent in the U.S. according to Han and Strange (2014), and a similar figure is estimated for the U.K. by Merlo and Ortalo-Magne (2004). Importantly, the price discount varies over the state of the housing markets, being small when housing markets are booming, while large downward price revisions are needed to sell the house in downturns, as for instance documented in Haurin et al. (2013) for the Belfast, U.K. market. ${ }^{2}$

The price discount is widely used in the U.S. and other advanced economies to gauge the "heat" of the housing markets, in the spirit of Carrillo (2013). This is not the case for Spain though, where the lack of available data limits the set of monitoring indices to a restricted number of statistics like the growth rate of housing prices, the volume of sales, or macroeconomic indicators such as unemployment or interest rates. This limitation is indeed a concern for real estate market participants, policymakers, and financial institutions for which monitoring the housing market cycle is a central task.

In this paper we employ unique and detailed data on home listings and transactions to construct and study the price discount in the Spanish housing markets, both from a national perspective as well as across regional submarkets. Importantly, Spain has experienced one of the most volatile housing markets over the recent years, as discussed in Akin et al. (2014). Moreover, substantial socio-economic disparities across regions have accompanied an uneven recovery of local housing submarkets after the last financial

\footnotetext{
${ }^{1}$ In the following we will use the terms asking price and list price interchangeably, as well as for transaction price and sale price.

${ }^{2}$ For the U.S. Horowitz (1992) has already emphasized that houses are routinely sold at prices below their list prices, while Jud et al. (1995) and Genesove and Mayer (2001) have documented that the price discount increases during market downturns.
} 
crisis, as shown in Alves and Urtasun (2019). These features make the Spanish real estate market a particularly interesting case study to test the performance of the price spread in tracking housing market conditions.

In order to guide our empirical analysis we rely on the theoretical framework of An et al. (2013), which is an extended version of the retail model developed in Lazear (1986). The model features a home seller which posts an asking price and optimally adjusts it after learning about the level of demand of potential buyers. Specifically, upon failing to sell the house at a given point in time, the seller realizes that the initial price was set too high, so that the price will be revised downwards. The key implication of this model is that the extent of the downward price revision depends on the state of the housing market cycle: with declining markets, the seller expects lower housing demand in the future and hence lower probability to sell the property, so that a larger price discount will be applied, and viceversa during upturns.

We empirically test this prediction by employing a unique and detailed dataset which includes more than five hundred thousand registries of matched home listings and transactions that occurred in Spain over the last decade. In particular, we exploit listings data provided by idealista: the largest real estate web portal in Spain whose database virtually consists of the universe of real estate properties that have been listed on the web. We combine these data with an administrative dataset that contains granular information on real estate transactions compiled by Spanish real estate registries. For each matched property we observe both asking and transaction prices, and thus the corresponding price discount.

We document that the price discount is strongly countercylical, as it increases with market downturns when housing demand is low, and viceversa during upturns. As shown in Figure 1, home sellers in Spain were on average accepting a discount by about 20.1 percent in 2012, the year which witnessed the worst stage of the Spanish housing and credit crises. The subsequent recovery led to a steady and dramatic decrease of the average price discount, which reached 9 percent by the end of 2018. At the regional level, we document a significant synchronization of housing market conditions among Spanish provinces, and a single common factor can account for about sixty percent of their variation. Finally, 
we document that the evolution of income, population, and interest rates, which are traditional proxies for housing demand, are jointly able to explain the bulk of variation of the price discount across regions and time. Taken altogether, these results support the idea that the price discount conveys useful information to track housing market conditions.

Figure 1: Average price discount in Spain

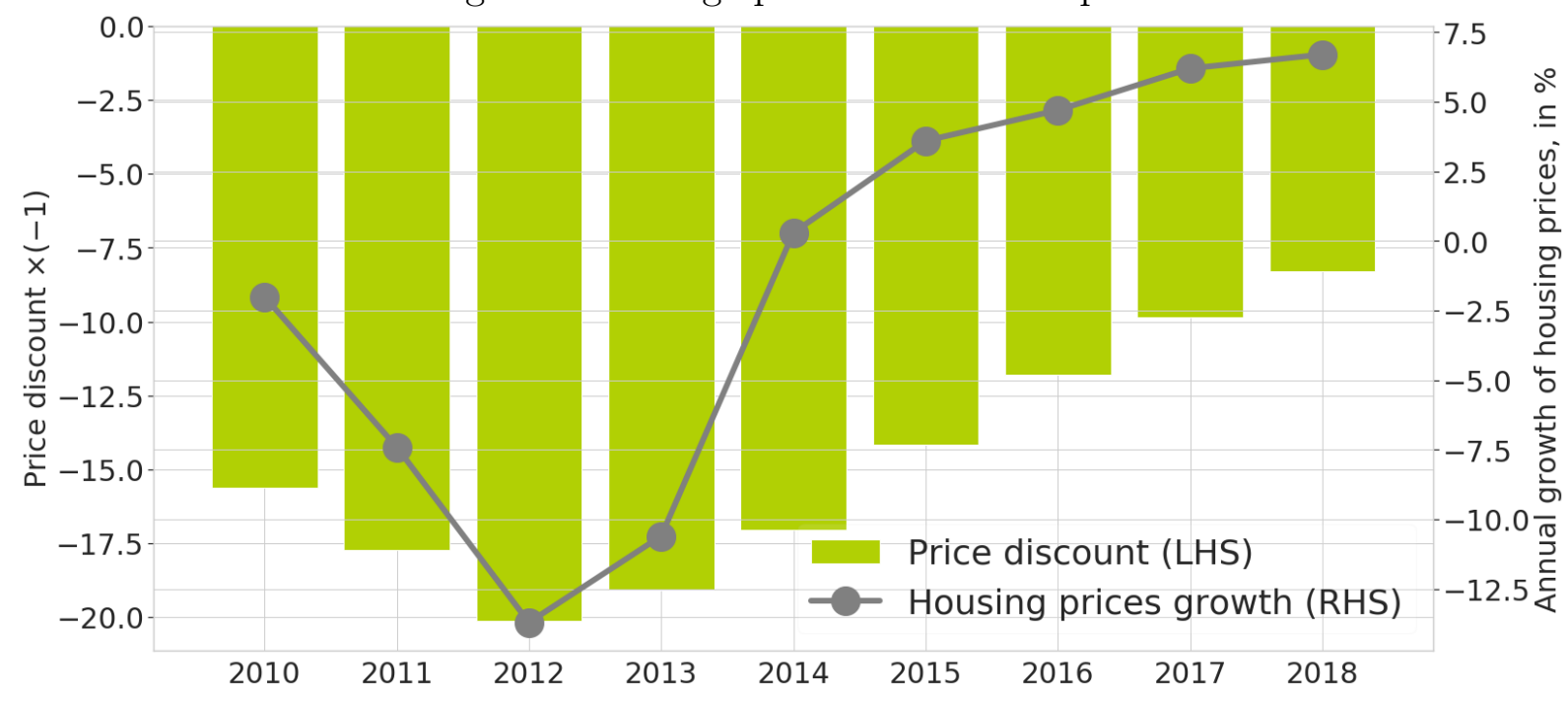

Note: Yearly frequency data, 2010-2018. Average price discount, as percent of the asking price, with minus sign for better readability. Annual growth of house price index Índice de Precios de Vivienda (IPV) from the Instituto Nacional de Estadística (INE).

The literature has proposed many indicators to gauge housing market conditions. As discussed in Anglin (2006), traditional measures consists of the growth of housing prices and the volume of sales, as well as macroeconomic indicators such as the unemployment and interest rates. These indicators, which mostly rely on administrative data from national statistical agencies, are generally available in most of countries. For the Spanish housing markets, a prominent example of applications of these measures can be found in BdE (2020). ${ }^{3}$ Additional indicators, which better reflect the idea that housing markets are intrinsically illiquid, include the time on the market (TOM), the price discount, and other

\footnotetext{
${ }^{3}$ These data also allow to identify periods of overvaluation in housing prices by estimating deviations of observed house prices from their unobserved equilibrium levels. In this sense, the estimated deviations are aimed to gauge the heat of the housing markets. In the context of the Spanish housing markets, earlier contributions focus on national data as in Martínez Pagés and Maza (2003) and Gimeno and Martínez-Carrascal (2010), while more recent studies employ panel data for the 50 Spanish provinces as in Álvarez-Lois and Nuño-Barrau (2007) and Álvarez Román and García-Posada (2019).
} 
measures of market tightness which are generally collected by private actors such as real estate agents. In the context of the U.S. and other advanced economies, these measures are generally available and several studies have empirically documented their relation with housing market conditions. For instance by focussing on marketing time, Genesove and Han (2012) employ U.S. survey data on buyers and sellers to document that the TOM decreases with demand, the latter being proxied by income and population. Carrillo and Pope (2012) exploit U.S. Multiple Listing Services (MLS) data to show that not only the mean or median TOM but the whole distribution varies over periods of hot and cold housing markets. By combining MLS data on TOM, list and sale prices, Carrillo (2013) constructs an index of seller's bargaining power which correctly captures upturns and downturns in home appreciation rates in the Washington, D.C. area. Moreover, Carrillo et al. (2015) document that measures of market tightness, such as seller's bargaining power and sale probabilities, help to predict future home price appreciations in the U.S. and the Netherlands. While relying on existing theoretical contributions, our study adds to this literature by documenting novel stylized facts about the price discount in Spanish housing markets.

The rest of the paper is organized as follows. Section 2 presents the theoretical model that guides our empirical investigation. Section 3 covers the data employed in the analysis. Section 4 describes the empirical analysis and reports results. Finally, last section concludes.

\section{Theoretical Framework}

In order to illustrate the relationship between the price discount and housing market conditions, we rely on existing literature that studies the determination of the asking price. In this respect there exist two separate but compatible theories: $(i)$ the search theory, which considers the asking price as a signaling device, see for instance Horowitz (1992), Yavas and Yang (1995), Haurin et al. (2010), Haurin et al. (2013), and Han and Strange (2016); and (ii) the theory of pricing under demand uncertainty, which provides insights on why the seller may want to revise the asking price, see for instance Knight 
(2002) and An et al. (2013). For illustrative purpose we rely on the framework of An et al. (2013) which, due to its simplicity, allows to obtain a closed-form relation between price discount and the state of the housing market cycle. ${ }^{4}$

The model extends the retail model developed in Lazear (1986) to allow for changing housing market conditions. The intuition of this framework is that, upon failing to sell the house at a given point in time, the seller realizes that the initial price was set too high relative to market demand, so that the asking price will be revised downwards. Specifically, the model consists of two periods indexed by $i=\{1,2\}$, one home seller and a continuum of potential buyers. At the beginning of period 1, the value of the house in period $1, V_{1}$, is uniformly distributed between zero and one, that is $V_{1} \sim U[0,1] .{ }^{5}$ At the beginning of period 2, the value of the house is $V_{2}=\alpha V_{1}$, where $\alpha$ captures time-varying future housing market conditions. In particular, $\alpha>1$ implies that prices are rising $V_{2}>V_{1}$ and the market is growing, viceversa if $\alpha<1$, and $\alpha=1$ implies a constant market as in Lazear (1986).

The seller's optimization problem amounts to set the reservation prices in both periods, $R_{1}$ and $R_{2}$, so to maximise expected profits

$$
\Pi=R_{1} \times \operatorname{Pr}(\text { Sale in } 1)+R_{2} \times \operatorname{Post} \operatorname{Pr}(\text { Sale in } 2) \times(1-\operatorname{Pr}(\text { Sale in } 1))
$$

where $\operatorname{Pr}($ Sale in 1$)$ is the probability of selling the property in period 1, while $\operatorname{Post} \operatorname{Pr}(\operatorname{Sale}$ in 2) is the posterior probability of sale in period 2. Given that $\operatorname{Pr}($ Sale in 1$)=1-R_{1}$ and $\operatorname{Post} \operatorname{Pr}($ Sale in 2$)=1-\frac{R_{2}}{\alpha R_{1}}$, the solution to this problem is given by the optimal seller's reservation prices

$$
R_{1}^{*}=\frac{2}{4-\alpha} \quad \text { and } \quad R_{2}^{*}=\frac{\alpha}{4-\alpha}
$$

\footnotetext{
${ }^{4}$ Indeed, the tractability of this model is partly due to the absence of search frictions, which are undoubtedly a relevant feature of housing markets. Several recent contributions that emphasize the role of search frictions for liquidity in housing markets are Novy-Marx (2009), which explains why housing market conditions, measured for instance by the ratio of buyers to sellers, expected TOM and transaction prices, are sensitive to fundamentals and get amplified by the search structure of property markets. Also, Diaz and Jerez (2013) show that search and matching frictions produce trading delays that augment the volatility of prices and propagate the effect of aggregate shocks to future periods. In a similar vein, Head et al. (2014) show that a random matching model can generate serial correlation in transaction prices growth even in the absence of persistent housing demand shocks. We refer to Han and Strange (2015) for a survey of the literature.

${ }^{5}$ For mathematical tractability, we follow An et al. (2013) in assuming that all potential buyers are seriously interested in purchasing the house and no shoppers are present.
} 
which state that prices in both periods are function of housing market conditions as measured by $\alpha$. In particular, Eq. (2) implies that

$$
\frac{d R_{1}^{*}}{d \alpha}=\frac{2}{(4-\alpha)^{2}}>0 \quad \text { and } \quad \frac{d R_{2}^{*}}{d \alpha}=\frac{4}{(4-\alpha)^{2}}>0
$$

so that reservation prices in both periods increase when housing market conditions improve. In particular, as $\alpha$ increases, valuations in period 2 rise and ceteris paribus the probability of selling the property in period 2 increases. Thus the seller finds it optimal to increase both reservation prices, as shown in panel (a) of Figure 2.

Figure 2: Reservation Prices, Price Discount, and Housing Market Conditions

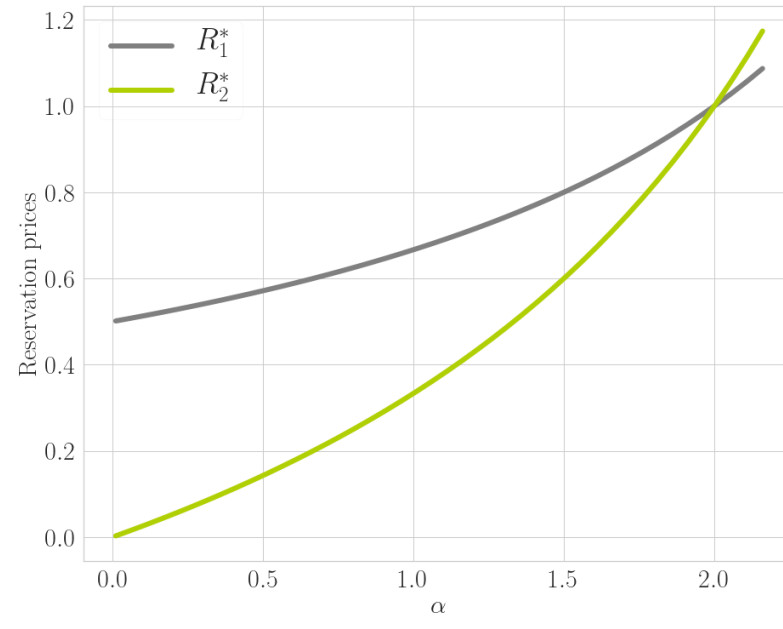

(a) Reservation Prices

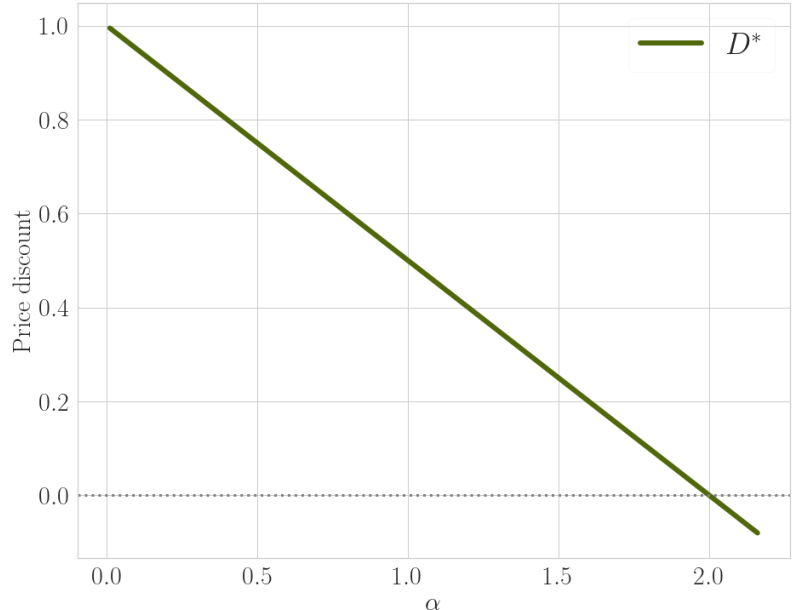

(b) Price Discount

Importantly, Eq. (3) also states that $d R_{1}^{*} / d \alpha<d R_{1}^{*} / d \alpha$ for any value of $\alpha$, so that the price in period 1 reacts less than price in period 2 to changes in future housing market conditions. This result is critical to explain the behavior of the optimal price discount, which from Eq. (2) is given by

$$
D^{*}=\frac{R_{1}^{*}-R_{2}^{*}}{R_{1}^{*}}=1-\frac{\alpha}{2}
$$

Given $d D^{*} / d \alpha=-\frac{d R_{2}^{*} / d \alpha}{d R_{1}^{*} / d \alpha}=-1 / 2<0$, the model predicts a negative relationship between the optimal price discount and housing market conditions, as shown in panel (b) of Figure 2. When markets are stable $(\alpha=1)$, it is optimal to apply a price discount equal to $D^{*}=1 / 2$. The reason is that as no sale occurred in the previous period, this implies that 
the price was set too high and should be cut in the next period. With declining markets $(\alpha<1)$, the seller expects lower future housing valuations and hence lower probability to sell the property, so that she will apply a larger price reduction. Specularly, the extent of the downward revision in price is lower with growing markets $(\alpha>1)$ as expected valuations are rising. In the case of very rapidly growing market conditions $(\alpha>2)$, the reservation price may be even higher in the second period, so that the resulting price discount becomes negative. ${ }^{6}$

In its simplicity, the model delivers a tractable and intuitive implication on the relationship between the price discount and housing market conditions. We test this implications in the following section, by exploiting data on regional housing markets for Spain.

\section{Data}

The data used in this study are from two sources. The primary data set is a large sample of property listings by idealista: the largest real estate web portal in Spain whose database virtually consists of the universe of real estate properties that have been listed on the web. This source of data contains the listing price as well as additional characteristics of the property such as the address, size, and typology of the property. The second source of data comes from the Spanish Recorders of Deeds Office and contains granular information on real estate transactions registered by Spanish real estate registries. For each transaction, we observe the sale price and date, as well as size and address (street number and name) of the house.

Both datasets on listings and transactions provide information about the typology, address, and area of the property, which we employ to perform the matching. ${ }^{7}$ The

\footnotetext{
${ }^{6} \mathrm{~A}$ negative price discount has been already empirically documented and rationalized in the literature, as in Han and Strange (2016) which document for the U.S. that the national share of above-list sales rose to around 15 percent during the 2000's boom. Haurin et al. (2013) documents that when the housing market in the Belfast, U.K. is particularly strong, homes sell for more than their list price, and the theoretical explanation relies on sellers switching behavior to an auction-like model during housing booms.

${ }^{7}$ We account for typos in street names, by employing a Levenshtein distance-based fuzzy string matching and accept only those matches which feature a partial ratio score that is above 80 percent. We verify that the matching procedure is accurate in virtually the totality of the matches. Moreover, as the prop-
} 
resulting dataset consists of 583,857 transactions of multi-family housing over the period January 2010 - June 2020. For each property $i$ transacted at time $t$, we compute the price discount $D_{i, t}$, that is the difference between asking and transaction prices as a fraction of the asking price,

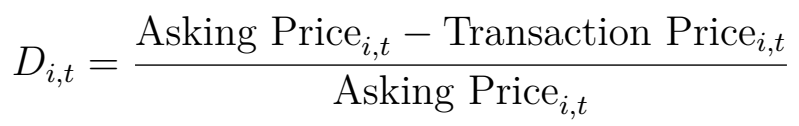

where Asking Price ${ }_{i, t}$ and Transaction Price $_{i, t}$ are the asking and transaction prices, both measured in euro per square meter, of property $i$ sold at time $t$.

We aggregate the micro data over time and space. In particular, we opt for annually sampled figures in order to allow for a sufficient observational coverage while at the same time keeping the frequency sufficiently high to be informative about the housing market's cycle. ${ }^{8}$ Since we are interested in constructing measures of housing market conditions at the regional level, we focus on the full set of 50 Spanish provinces, and we also include the autonomous cities of Ceuta and Melilla. While other studies limit the analysis of housing markets to the 17 Spanish autonomous communities as in BdE (2020), our relatively larger dataset allows for a finer geographical disaggregation. Province-specific measures are constructed in two steps. First, we calculate median statistics at the final zone per year level, where a final zone is defined as an area that does not contain children areas (i.e. sub-areas) and thus represents the finest grain of the geographical breakdown. ${ }^{9}$ Then, figures at the province (or also nation) per year levels are computed as weighted averages of final zone metrics, by using one-year window rolling weights based on the number of transactions.

erty area from the advertisement is typically larger than the reported figure in transaction, we allow for an absolute discrepancy of no more than $50 \%$ with respect to the area reported in transaction. To further ensure consistency of the matching, we rule out the following outlier cases: $(i)$ instances in which the asking or transaction price is below 10,000 euro, $(\mathrm{ii})$ any potential match that would imply an extremely large time on the market, which is set to 36 months, or (iii) an extremely large price discount above 100 percent in absolute terms.

${ }^{8}$ This choice also rules out the effects of seasonal factors for real estate markets, which have been already emphasized in the literature. In particular, Salant (1991) applies housing search in a nonstationary setting with a fixed house sale season and shows that asking prices may flucutate over the season despite the model featuring constant arrival probability of buyers. In Ngai and Tenreyro (2014), a search and matching model is employed to illustrate how seasonal factors may generate seasonal patterns in transactions and prices due to thick market effects.

${ }^{9}$ Depending on the sample coverage, a final zone may refer to a neighborhood, a district, or a municipality. 
Tables 3 and 4 display the descriptive statistics of asking and transaction prices and the corresponding price discount, averaged over the years 2010-2018. Over the full sample period, the price discount in Spain averages 14.9 percent, with the lowest and highest figures being respectively 9.9 percent in the province of Madrid and 25.4 percent in Ourense. Despite the large heterogeneity across provinces, these statistics mask substantial variation over time. As it will be shown in the next section, this time variation intrinsically depends on the state of the housing markets.

\section{Empirical Analysis}

\subsection{Price Discount and Housing Market Conditions in Spain}

In the following we study the relationship between the price discount and housing market conditions in Spain, first by providing an overview at the national level, and then by conducting an in-depth analysis of regional submarkets. From Eq. (4), the model delivers a negative relation between the optimal price discount and the parameter $\alpha$, which measures the overall change in housing valuations, $\alpha=V_{2} / V_{1}$, and which is meant to capture housing market conditions. To operationalize Eq. (4), we relate our estimated price discount, measured at yearly frequency, to the annual growth of housing prices which serves as a proxy for changes in housing valuations as captured by $\alpha$.

Figure 1 plots the time series of the average price discount for Spain, joint with the annual percent change of housing prices provided by the Spanish national statistical agency. ${ }^{10}$ The price discount tracks well the Spanish experience over the last decade. Right after the first financial crisis, housing market conditions in Spain were declining: in 2010, housing prices were falling by about 2 percent year-on-year, and the home-owners were accepting on average reductions of the asking price by about 15.6 percent. ${ }^{11}$ The situation subsequently worsened at the onset of the Spanish banking and sovereign debt crises in 2012, in which Spain witnessed a dramatic fall in house prices by about -13.7 percent, and the

\footnotetext{
${ }^{10}$ Specifically, the housing price index we employ is the Índice de Precios de Vivienda (IPV) published by the Instituto Nacional de Estadística (INE).

${ }^{11}$ As emphasized for instance in Akin et al. (2014), the boom and the bust in the housing market, and the associated credit cycle, appear to be the main drivers of the crises that hit many advanced countries such as the U.S., U.K., Ireland, and Spain.
} 
average price discount reached its peak by averaging 20.1 percent. Following this significant correction, housing market conditions restored in 2014, when housing prices started to grow and subsequently reached the peak appreciation in $2018(+6.7$ percent), while in the same year the price discount averaged 9 percent. $^{12}$

Figure 3: Price Discount by Province: Crisis and Recovery Periods

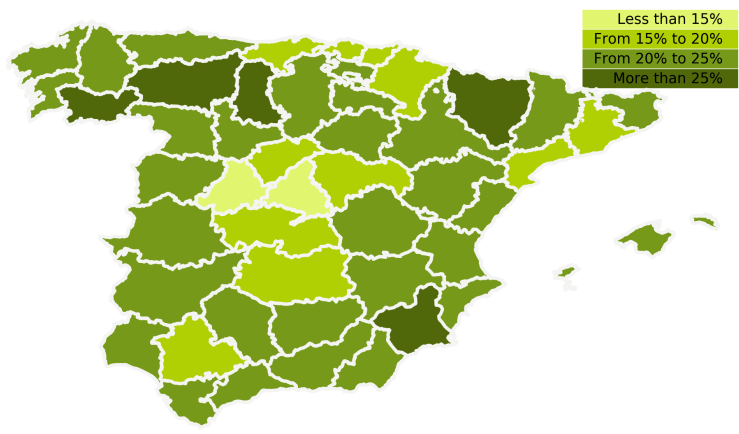

(a) Crisis period (2010-2014)

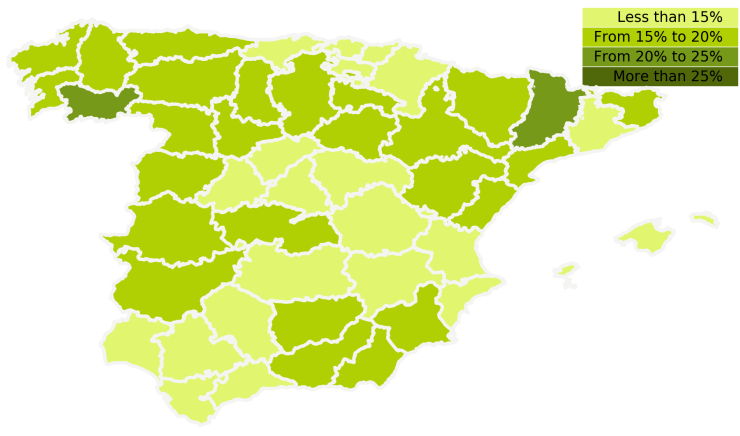

(b) Recovery period (2015-2018)

Note: Price discount per province, in percent of asking price. Crisis period refers to average of yearly figures 2010-2014, Recovery period refers to average of yearly figures 2015-2018.

The reported evidence suggests that the evolution of the price discount is strongly related to developments in the housing market. This result is even starker when analyzing regional submarkets. Figure 3 plots the average price discount by province over the crisis (2010-2014) and recovery (2015-2018) periods. During the crisis, we observe that the price discount is generally high in most of the provinces. Out of the 50 provinces, 35 provinces feature price discounts higher than 20 percent, with the highest figures being observed in Ourense (27.5 percent), Murcia (26.8 percent), and Leon (25.7 percent). Madrid stands out as one of the provinces with lowest price discount (13.8 percent), and similarly for Barcelona (18.5 percent). Conversely, the recovery period witnesses a generalized and dramatic fall in price discounts. With the exception of Ourense (22.9 percent) and Lleida (20.1 percent), all provinces feature an average discount below 20 percent, with the lowest values being observed in the provinces of Madrid (5 percent), Barcelona (8.6 percent) and

\footnotetext{
${ }^{12}$ Over the recovery. the house price appreciation has been accompanied by improvements in other real estate indicators. For instance, BdE (2020) documents that households' housing investment rose by 47 percent in real terms between 2013 and 2019, and that new housing starts or construction sector employment have also been expansionary over the same period.
} 
the Balearic islands (9.3 percent).

Table 1 examines how the regional price discount varies in response to changes in transaction prices, the latter serving as a proxy for housing market conditions. Standard errors are robust and clustered at the province and year levels, and each province-year observation is weighted by the underlying number of transactions to adjust for heteroskedasticity. Further, we compare results of a standard pooled regression with an alternative specification which includes both province and year effects.

Table 1: Regional Price Discount and Housing Market Conditions

\begin{tabular}{|c|c|c|c|c|c|c|}
\hline & \multicolumn{2}{|c|}{ Price Discount } & \multicolumn{2}{|c|}{ Asking Price } & \multicolumn{2}{|c|}{ Transaction Price } \\
\hline & $(1)$ & $(2)$ & $(3)$ & $(4)$ & $(5)$ & $(6)$ \\
\hline$\Delta$ House Prices & $\begin{array}{c}-0.433^{* * *} \\
(0.048)\end{array}$ & $\begin{array}{c}-0.120^{* * *} \\
(0.022)\end{array}$ & $\begin{array}{c}0.060 \\
(0.213)\end{array}$ & $\begin{array}{l}0.279^{* *} \\
(0.121)\end{array}$ & $\begin{array}{c}0.673^{* * *} \\
(0.288)\end{array}$ & $\begin{array}{r}0.518^{* * *} \\
(0.132)\end{array}$ \\
\hline Constant & $\begin{array}{c}0.131^{* * *} \\
(0.013)\end{array}$ & & $\begin{array}{c}7.478^{* * *} \\
(0.088)\end{array}$ & & $\begin{array}{c}7.316^{* * *} \\
(0.103)\end{array}$ & \\
\hline $\begin{array}{l}\text { Province F.E. } \\
\text { Year F.E. }\end{array}$ & $\begin{array}{l}\text { No } \\
\text { No }\end{array}$ & $\begin{array}{l}\text { Yes } \\
\text { Yes }\end{array}$ & $\begin{array}{l}\mathrm{No} \\
\mathrm{No}\end{array}$ & $\begin{array}{l}\text { Yes } \\
\text { Yes }\end{array}$ & $\begin{array}{l}\text { No } \\
\text { No }\end{array}$ & $\begin{array}{l}\text { Yes } \\
\text { Yes }\end{array}$ \\
\hline N. Obs. & 416 & 416 & 416 & 416 & 416 & 416 \\
\hline
\end{tabular}

Note: The main data source is the micro-level matched listings-transactions data, aggregated to the province/year level. Regressions are at the province $\times$ year level, weighted by the number of individual transactions in the given province for the given year. Robust standard errors clustered at the province and year levels are reported in brackets. Asking and transaction prices are in logs, $\Delta x$ indicates annual (log-)changes. ${ }^{*},{ }^{* *}$, and ${ }^{* * *}$ denote significance at the 10,5 , and 1 percent, respectively.

Columns (1) and (2) regress the price discount on the annual change in transaction prices. Results suggest that smaller price discounts are observed in those areas which feature higher house prices growth, and the estimated relationship is significant at 1 percent of significance in both specifications. These findings validate the model's key prediction of a countercyclical price spread. To better understand this result, we further regress the (log-) asking and transaction prices on changes in house prices. As shown in columns (3) and (4), the asking price positively reacts to increases in house prices, but the estimated elasticity is not statistically significant when not accounting for province and year effects. Conversely, columns (5) and (6) document that the effect on the transaction 
price is relatively larger, as well as statistically significant. These findings jointly confirm Eq. (3) of the model, which predicts that asking and transaction prices both increase when housing market conditions improve, but since the asking price reacts more sluggishly, the price discount negatively comoves with the housing market cycle. ${ }^{13}$

These results support the idea that the price discount conveys useful information to track the state of housing markets. In the following sections, we will shed light on which factors could be driving changes in housing market conditions.

\subsection{Synchronization of the Price Discount across Regions}

In the previous section we have provided evidence that regional price discounts tend to react to changes in housing market conditions. One relevant question that we ask is which are the key drivers that affect the tightness of real estate markets. To answer this question, the regional dimension of the data is particularly useful to first understand whether the driving factors are common across regions or depend on specific characteristics of provinces. If drivers are common, such as a nationwide recession accompanied by a generalized drop in credit and activity, then we should observe substantial synchronization across regions. In order to answer this question, we estimate the following model,

$$
\tilde{D}_{i, t}=\beta_{i} f_{t}+\varepsilon_{i, t}
$$

where $\tilde{D}_{i, t}$ is the standardized (zero-mean and unit variance) price discount of province $i, f_{t}$ is an unobserved common factor that captures widespread developments across provinces and which features zero mean and normalized variance equal to one, $\varepsilon_{i, t}$ is an idiosincratic disturbance with zero mean and variance $\sigma_{i}^{2}$ that is uncorrelated with the common factor so to capture province-specific developments, and $\beta_{i}$ is the elasticity of province- $i$ price discount to the common factor. ${ }^{14}$

\footnotetext{
${ }^{13}$ This result is consistent with findings in Haurin et al. (2013), which show that during a downturn in the Belfast, U.K. housing market, seller's list prices are sticky. Moreover, using data on transaction histories for residential properties in England, Merlo et al. (2015) document the high degree of stickiness of listing prices.

${ }^{14}$ Principal component analysis is a widespread method to estimate common components. Using this approach, Hirata et al. (2013) examine the properties of house price fluctuations across eighteen advanced economies and document a large synchronization of house prices across countries, which has also increased over time.
} 
Figure 4 reports the estimated elasticities of the province-specific price spread, $\hat{\beta}_{i}$, in percentage points. Most of estimated elasticities are positive, which implies that common drivers which affect national housing market conditions lead to synchronized movements in regional price discounts. There is heterogeneity in the size of the elasticities, which indicates that some regions are more strictly tied to the national housing cycle than others. In particular, the ten most responsive provinces which feature on average an elasticity equal to 98 percent, would observe an increase of their price discounts by 98 percent due to a 100 percent increase in the national factor. Conversely, price discounts in the province of Segovia and in the autonomous city of Melilla, whose elasiticities are not statistically different from zero, would feature negligible reponses to changes in the common factor.

Figure 4: Regional Elasticities to Nationwide Housing Market Conditions

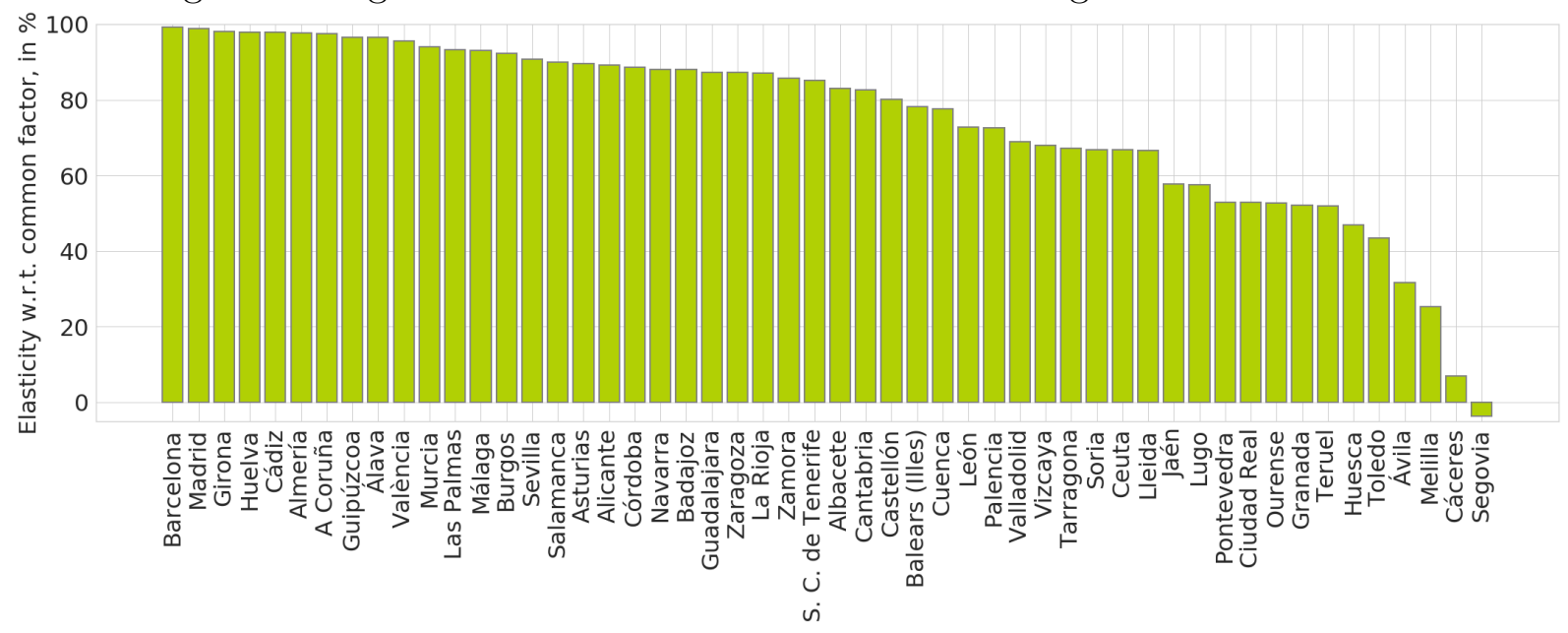

Note: Estimated elasticities of the province-specific (normalized) price spread to the estimated common factor, $\hat{\beta}_{i}$.

An alternative and complementary way to gauge the extent of regional comovement is to report the share of variance of regional price spreads that is explained by the common factor. Given that each province-specific disturbance $\varepsilon_{i, t}$ is by construction uncorrelated with the common factor, from Eq. (6) we can also decompose the variance of each 
province-specific price discount as,

$$
\begin{aligned}
\operatorname{Var}\left(\tilde{D}_{i, t}\right) & =\operatorname{Var}\left(\beta_{i} f_{t}+\varepsilon_{i, t}\right) \\
& =\beta_{i}^{2} \operatorname{Var}\left(f_{t}\right)+\operatorname{Var}\left(\varepsilon_{i, t}\right) \\
& =\beta_{i}^{2}+\sigma_{i}^{2}
\end{aligned}
$$

Since the price discount is normalized to have unit variance, $\operatorname{Var}\left(\tilde{D}_{i, t}\right)=1$, the estimated share of variance of price discount in province $i$ that is explained by the common factor is given by $\hat{\beta}_{i}^{2}$.

Figure 5 reports the estimated shares of variance explained by the common factor, and confirms the relevance of common developments in accounting for most of regional variation in price discounts. The single common factor accounts for more than half of the variation in the price discount for most provinces (33 areas out of 52 including Ceuta and Melilla), and on average it explains about 61.5 percent of variation in regional price discounts.

Figure 5: Share of Variance Explained by the Common Factor

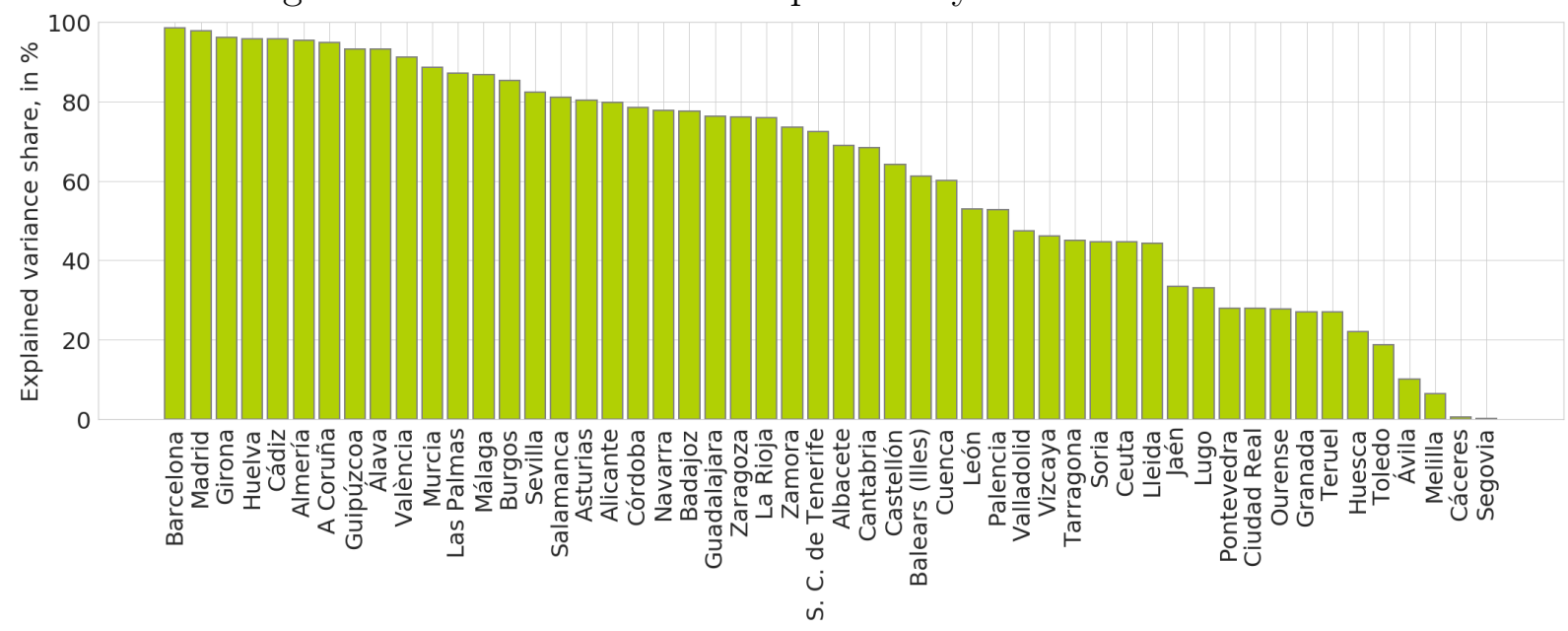

Note: Estimated shares of variance of the province-specific price discount explained by the common factor.

To summarize, this section documents a strong synchronization of price discounts across Spanish provinces. This finding suggests that nationwide factors play a relevant role in shaping local housing market conditions. We then ask which factors are responsible for driving the evolution of real estate markets. This question will be tackled in the next 
section, in which we explore the relation between regional price discounts and a number of demographic and macroeconomic indicators which have been traditionally employed as proxies for housing demand.

\subsection{Determinants of the Price Discount}

We have shown that regional price discounts are intrinsically related to housing market conditions, and also that nationwide drivers summarised by a single common factor can account for most of their variation. In this section we identify which specific factors may affect the evolution of housing market conditions via shifts in housing demand. ${ }^{15}$ In selecting proxies for housing demand, we follow the existing literature which traditionally employs measures of population, income growth and borrowing rates. In particular, Genesove and Han (2012) proxy housing demand by income and population (both levels and growth rates), and document that these factors significantly affect a set of U.S. MSA-specific housing market liquidity indicators such as the time on the market of both buyers and sellers, as well as the number of homes that are visited by buyers. Focussing on the price discount, Jud et al. (1995) use MLS data for Greensboro, North Carolina to document that the asking-transaction price spread positively correlates with interest rates that proxy for transaction costs and the macroeconomic cycle. ${ }^{16}$

\footnotetext{
${ }^{15}$ Trough the lenses of our model, the parameter $\alpha$ which enters in Eq. (4) summarizes in a reduced form way the joint effect of all those demand shifters that affect market conditions.

${ }^{16}$ Other papers include Glaeser and Gyourko (2005), which employ long-run U.S. data to document that population growth and house price growth are positively correlated. Wheaton and Nechayev (2008) employ population, income growth and interest rates as demand fundamentals to assess the evolution of housing prices for 59 U.S. MSA markets. Anundsen and Jansen (2013) document for Norway a long-run relation between housing prices and credit, and that interest rates and households' expected future income matter for the determination of housing prices. Related to demographics, Eichholtz and Lindenthal (2014) exploit data from a survey of English households and show that demand of residential real estate depends on demographic characteristics and income. Moreover, Damen et al. (2016) construct a measure of borrower's ability to pay, which includes the effect of changes in interest rate, mortgage interest deduction and mortgage characteristics, and show that it tracks the long-run trend of house prices for several advanced economies.
} 
Figure 6: Housing Demand Proxies and Price Discount

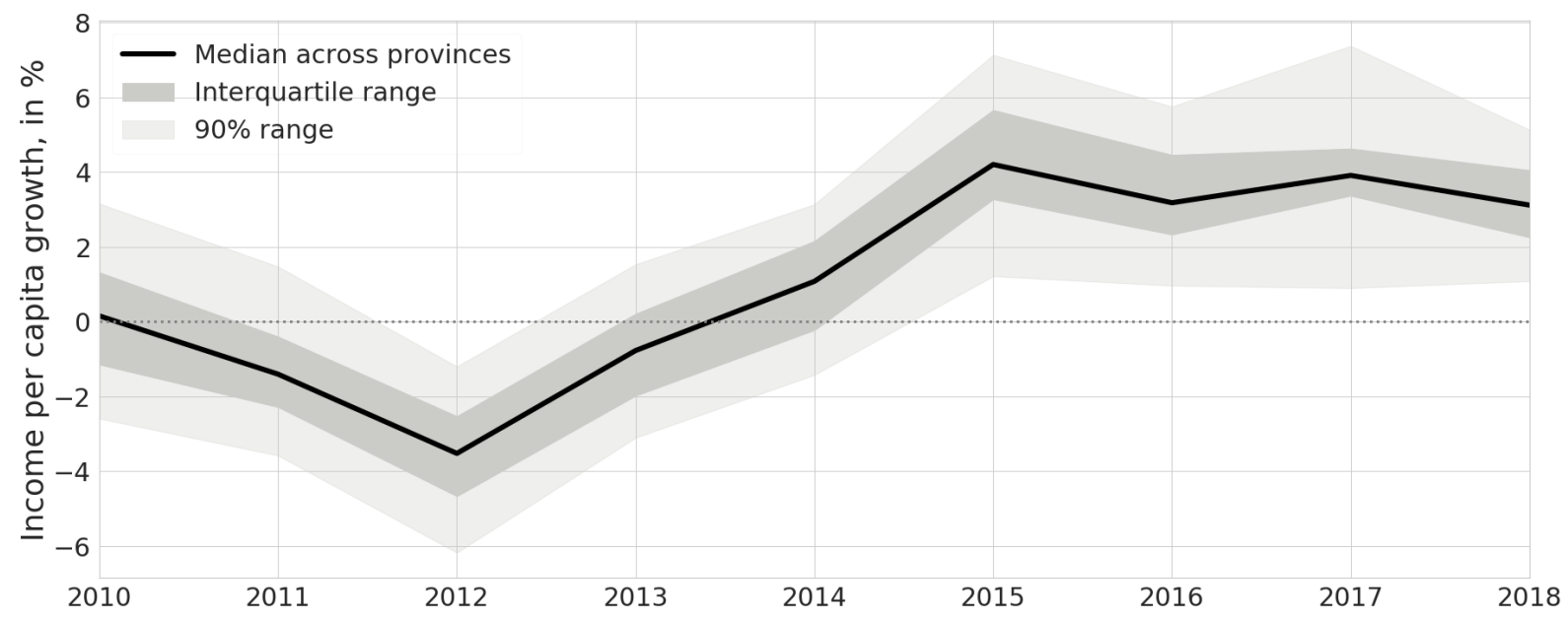

(a) Income growth

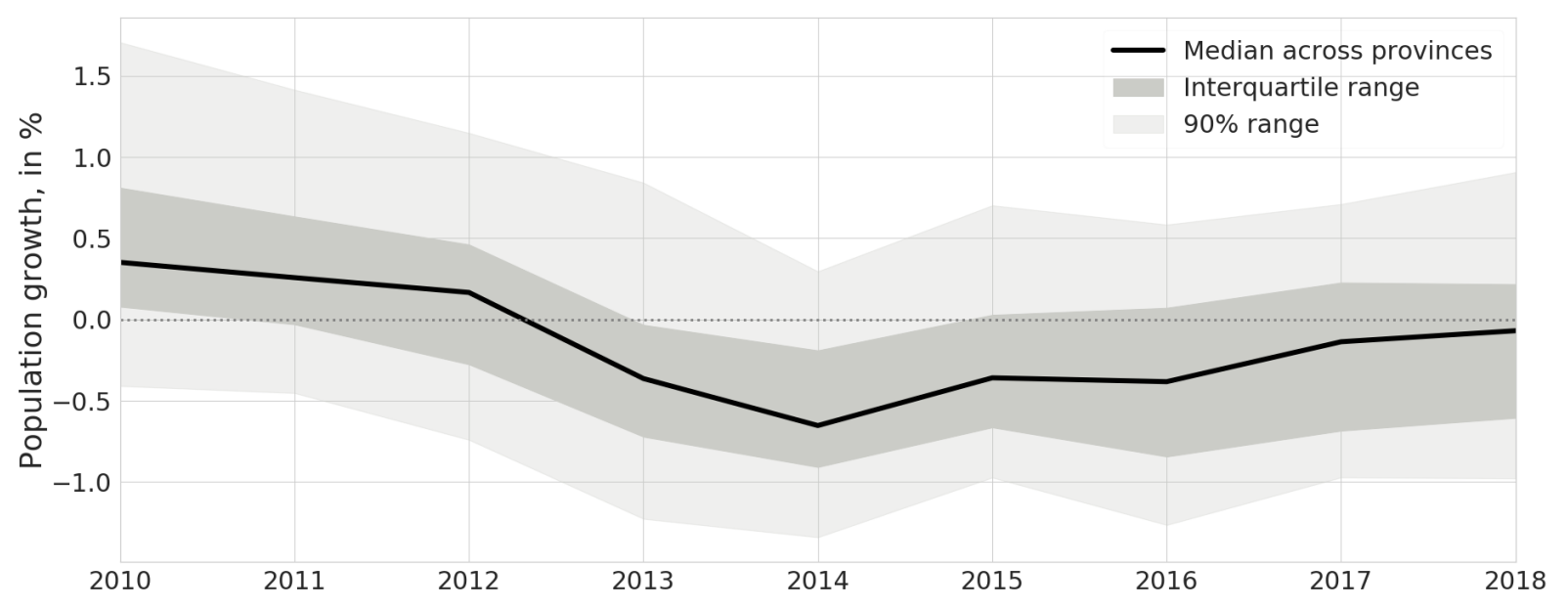

(b) Population growth

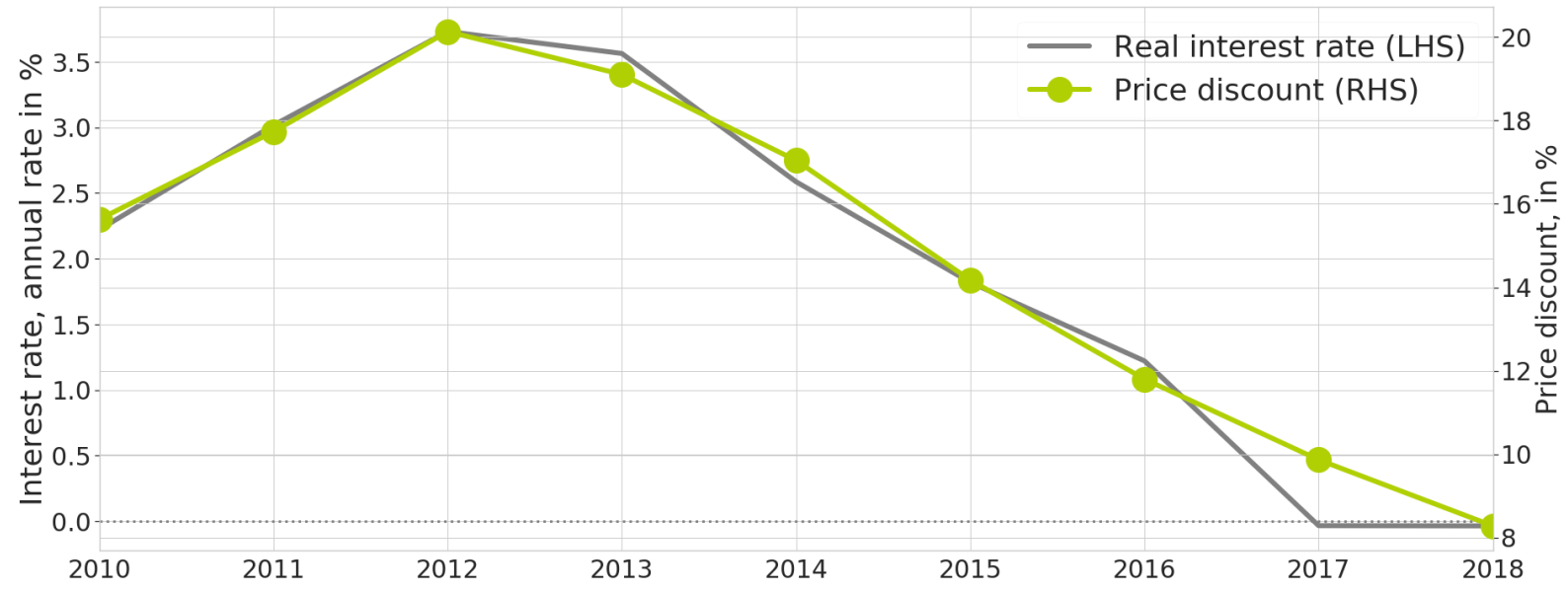

(c) Real long-term interest rate

Note: Yearly frequency data, 2010-2018. Income per capita and population yearly growth rate \%, real long-term interest rate, annual rate in \%, and average price discount for Spain, as percent of the asking price. 
Accordingly, Figure 6 reports the set of housing demand proxies which we employ in our analysis. ${ }^{17}$ Panel (a) plots the cross-provinces distribution of income per capita growth over time. The evolution of income growth mimics well the dynamics of the price discount and housing prices growth as previously reported in Figure 1. The median annual growth, which is about 0.15 percent at the beginning of the sample, decreases thereafter and averages -3.5 percent at the onset of the Spanish banking crisis in 2012. After 2014, once the recovery sets stage, the entire distribution shifts into positive territory with a median growth fluctuating in between 3 and 4 percent. Importantly, the relatively narrow interquartile and 90\% bands suggest a strong comovement across provinces. Panel (b) plots the distribution for population growth across provinces, and documents that the distribution shifts downwards over the period 2010-2014 when housing market conditions are declining, while it stabilizes with the recovery. Finally, Panel (c) plots the real longterm interest rate for Spain. Interest rates are high over the crisis period and peak in 2012, then revert afterwards reaching low levels by the end of the sample. Importantly, the figure also shows that interest rates and the price discount comove, similarly to what found by studies that focus on the U.S. experience, see for instance Jud et al. (1995).

Table 2 examines how the price discount varies in response to changes in the housing demand proxies. Standard errors are robust and clustered at the province and year levels, and each province-year observation is weighted by the underlying number of transactions to adjust for heteroskedasticity. First, we regress in column (1) the price discount on the demographic determinants: the (log-)level of population and its annual growth. Both level and growth rate of population negatively affect the price discount, and these determinants alone are able to explain more than half (55 percent) of variation in regional price discounts. This result supports the narrative of the Spanish experience in BdE (2020),

\footnotetext{
${ }^{17}$ Province per year data on income and population come from the Eurostat database. Income is measured by the province-level gross domestic product measured at current market prices. For each province (NUTS3-level), the latest available data point is 2017, while the latest year is 2018 for the corresponding autonomous community (NUTS2-level). We thus perform an imputation as follows. First, for each province we regress the (log-)GDP NUTS3 level on a constant and the (log-)GDP of its corresponding NUTS2 region. We then use the estimated coefficients and the 2018 NUTS2 GDP value to impute the missing entry. Province-level population figures allow for calculating the income per capita. Finally, since interest rates are only available at the national level, we employ the Spanish series of long-term real interest rate which come from the Eurostat-Ameco database.
} 
which documents that the uneven Spanish recovery over the recent years can be partly explained by differentials in population growth across regions. Column (2) regresses the price discount on the (log-)level of income per capita and its growth rate. Economically developed areas feature smaller price discount, as well as areas with greater income growth. Column (3) includes as regressors both demographic and economic determinants: previous estimates are largely preserved, and these factors jointly account for about 75 percent of variation in the price discount.

Table 2: Regional Price Discount and Housing Demand

\begin{tabular}{lcccc}
\hline \hline & $(1)$ & $(2)$ & $(3)$ & $(4)$ \\
\hline Population & $-0.018^{* * *}$ & & $-0.015^{* * *}$ & $-0.022^{* * *}$ \\
& $(0.003)$ & & $(0.003)$ & $(0.003)$ \\
$\Delta$ Population & $-5.627^{* * *}$ & & $-5.109^{* * *}$ & $-2.860^{* * *}$ \\
& $(0.900)$ & & $(0.615)$ & $(0.228)$ \\
Income per Capita & & $-0.127^{* * *}$ & $-0.049^{* * *}$ & $-0.040^{* * *}$ \\
& & $(0.028)$ & $(0.011)$ & $(0.012)$ \\
$\Delta$ Income per Capita & & $-0.953^{* * *}$ & $-1.058^{* * *}$ & $-0.226^{* *}$ \\
& & $(0.234)$ & $(0.213)$ & $(0.098)$ \\
Interest Rate & & & & $2.213^{* * *}$ \\
& & & & $(0.231)$ \\
Constant & $0.396^{* * *}$ & $-0.318^{* * *}$ & $0.190^{* *}$ & $0.275^{* * *}$ \\
& $(0.045)$ & $(0.104)$ & $(0.076)$ & $(0.060)$ \\
\hline Number of observations & 468 & 468 & 468 & 468 \\
$\mathrm{R}^{2}$ & 0.55 & 0.44 & 0.75 & 0.85 \\
\hline \hline
\end{tabular}

Note: The main data source is the micro-level matched listings-transactions data, aggregated to the province/year level. Regressions are at the province $\times$ year level, weighted by the number of individual transactions in the given province for the given year. Robust standard errors clustered at the province and year levels are reported in brackets. The dependent variable is the price discount, computed as $\left(P^{A S K}-P^{T X N}\right) / P^{A S K}$. Population and income per capita are in logs, $\Delta x$ indicates annual (log-)changes. ${ }^{*}, * *$, and $* * *$ denote significance at the 10,5 , and 1 percent, respectively.

Finally, column (4) considers all demographic and macroeconomic factors jointly, by additionally including the real long-term interest rate. We point out several interesting results. First, the estimates of population and income factors are preserved in sign and statistical significance, and we find higher sensitivity to growth of demand rather than 
levels, consistently with findings in Genesove and Han (2012). Second, the interest rate positively and significantly affects the price discount. These findings are in line with Alves and Urtasun (2019), according to which the recent dynamism in Spanish housing markets is attributable, among other factors, to the positive evolution of the labor market and low financing costs. And third, all factors jointly account for the bulk (roughly 85 percent) of the variation in regional price discounts.

Taken altogether, these results strengthen the idea that the price discount conveys useful information to measure liquidity in housing markets. In particular, this section concludes that most of the regional movements in the price discount are economically meaningful as they can be explained by standard factors that affect market tightness. Further, this result also suggests that in those situations in which neither detailed information about transaction prices, nor comprehensive demand data from realtors are available, data on regional macroeconomic and demographic indicators provide a relatively good approximation to gauge the heat of housing markets.

\section{Conclusions}

In this paper we employ unique and detailed data on home listings and transactions to construct and study the price discount in the Spanish housing markets, both from a national perspective as well as across regional submarkets. Spain features one of the most volatile housing markets as well as large heterogeneity amongst regional submarkets. These features make the Spanish real estate market a particularly interesting case study to test the performance of the price spread in tracking housing market conditions.

In order to guide our empirical analysis we rely on the theoretical framework of An et al. (2013), whose key implication is that the extent of the price discount depends on the state of the housing market cycle: with declining markets, the seller expects lower future demand and hence lower probability to sell the property so that a larger price discount will be applied, and viceversa during upturns.

We indeed find that the price discount is strongly countercylical, as it increases with market downturns when housing demand is low, and viceversa during upturns. We 
also document a significant synchronization of housing market conditions among Spanish provinces, and a single common factor can account for about sixty percent of their variation. This finding suggests that nationwide factors play a relevant role in shaping local housing market conditions in Spain. We finally show that the evolution of income, population, and interest rates are jointly able to explain the bulk of variation of the price discount across regions and time.

This evidence also suggests that data on regional macroeconomic and demographic indicators can be potentially exploited in order to infer housing market conditions for those regions where neither detailed information about transaction prices, nor comprehensive demand data from realtors are available. In this respect, extrapolated housing market liquidity measures could be an important building block to inform and extend the HouseLev dataset, which currently includes house price levels for 40 advanced and emerging economies, see Bricongne et al. (2019). We leave this interesting possibility for future research. 


\section{References}

Akin, O., Montalvo, J. G., Villar, J. G., Peydró, J. L., and Raya, J. M. (2014). The real estate and credit bubble: evidence from Spain. SERIEs, 5(2-3), 223-243.

Álvarez-Lois, P., and Nuño-Barrau, G. (2007). A Panel Cointegration Analysis of the Real State Market: Theory and Evidence from Spanish Provinces. Documento de Trabajo, Servicio de Estudios BBVA, España.

Álvarez Román, L., and García-Posada, M. (2019). Modelling regional housing prices in Spain. Documentos de trabajo, Banco de España, 1941.

Alves, P., and Urtasun, A. (2019). Recent housing market developments in Spain. Banco de Espana Analytical Article, 4, 19.

An, Z., Cheng, P., Lin, Z., and Liu, Y. (2013). How do market conditions impact priceTOM relationship? Evidence from real estate owned (REO) sales. Journal of Housing Economics, 22(3), 250-263.

Anglin, P. M. (2006). Value and liquidity under changing market conditions. Journal of Housing Economics, 15(4), 293-304.

Anundsen, A. K., and Jansen, E. S. (2013). Self-reinforcing effects between housing prices and credit. Journal of Housing Economics, 22(3), 192-212.

Banco de España (2020). The housing market in Spain: 2014-2019. Documentos Ocasionales n.2013, Directorate General Economics, Statistics and Research, Banco de Espaã.

Bricongne, J. C., Turrini, A., and Pontuch, P. (2019). Assessing house prices: insights from Houselev, a Dataset of Price Level Estimates. European Commission, European Economy Discussion Paper 101.

Carrillo, P. E., and Pope, J. C. (2012). Are homes hot or cold potatoes? The distribution of marketing time in the housing market. Regional Science and Urban Economics, 42(12), 189-197. 
Carrillo, P. E. (2013). To sell or not to sell: Measuring the heat of the housing market. Real estate economics, 41(2), 310-346.

Carrillo, P. E., de Wit, E. R., and Larson, W. (2015). Can tightness in the housing market help predict subsequent home price appreciation? Evidence from the United States and the Netherlands. Real Estate Economics, 43(3), 609-651.

Damen, S., Vastmans, F., and Buyst, E. (2016). The effect of mortgage interest deduction and mortgage characteristics on house prices. Journal of Housing Economics, 34, 15-29.

Diaz, A., and Jerez, B. (2013). House prices, sales, and time on the market: A searchtheoretic framework. International Economic Review, 54(3), 837-872.

Eichholtz, P., and Lindenthal, T. (2014). Demographics, human capital, and the demand for housing. Journal of Housing Economics, 26, 19-32.

Elder, H. W., Zumpano, L. V., and Baryla, E. A. (1999). Buyer search intensity and the role of the residential real estate broker. The Journal of Real Estate Finance and Economics, 18(3), 351-368.

Genesove, D., and Han, L. (2012). Search and matching in the housing market. Journal of Urban Economics, 72(1), 31-45.

Genesove, D., and Mayer, C. (2001). Loss aversion and seller behavior: Evidence from the housing market. The Quarterly Journal of Economics, 116(4), 1233-1260.

Gimeno, R., and Martínez-Carrascal, C. (2010). The relationship between house prices and house purchase loans: The Spanish case. Journal of Banking 6 F Finance, 34(8), 1849-1855.

Glaeser, E. L., and Gyourko, J. (2005). Urban decline and durable housing. Journal of Political Economy, 113(2), 345-375.

Han, L., and Strange, W. C. (2014). Bidding wars for houses. Real Estate Economics, 42(1), 1-32. 
Han, L., and Strange, W. C. (2015). The microstructure of housing markets: Search, bargaining, and brokerage. In Handbook of Regional and Urban Economics (Vol. 5, pp. 813-886). Elsevier.

Han, L., and Strange, W. C. (2016). What is the role of the asking price for a house? Journal of Urban Economics, 93, 115-130.

Haurin, D. R., Haurin, J. L., Nadauld, T., and Sanders, A. (2010). List prices, sale prices and marketing time: an application to US housing markets. Real Estate Economics, 38(4), 659-685.

Haurin, D., McGreal, S., Adair, A., Brown, L., and Webb, J. R. (2013). List price and sales prices of residential properties during booms and busts. Journal of Housing Economics, $22(1), 1-10$.

Head, A., Lloyd-Ellis, H., and Sun, H. (2014). Search, liquidity, and the dynamics of house prices and construction. American Economic Review, 104(4), 1172-1210.

Hirata, H., Kose, M. A., Otrok, C., and Terrones, M. (2013). Global House Price Fluctuations: Synchronization and Determinants. In NBER International Seminar on Macroeconomics 2012. University of Chicago Press.

Horowitz, J. L. (1992). The role of the list price in housing markets: theory and an econometric model. Journal of Applied Econometrics, 7(2), 115-129.

Jud, G. D., Winkler, D. T., and Kissling, G. E. (1995). Price spreads and residential housing market liquidity. The Journal of Real Estate Finance and Economics, 11(3), 251-260.

Khezr, P. (2015). Time on the market and price change: the case of Sydney housing market. Applied Economics, 47(5), 485-498.

Knight, J. R. (2002). Listing price, time on market, and ultimate selling price: Causes and effects of listing price changes. Real Estate Economics, 30(2), 213-237. 
Lazear, E. (1986). Retail Pricing and Clearance Sales. American Economic Review, 76(1), $14-32$.

Martínez Pagés, J., and Maza Lasierra, L. A. (2003). Análisis del precio de la vivienda en España. Documentos de trabajo, Banco de España, 0307.

Merlo, A., and Ortalo-Magne, F. (2004). Bargaining over residential real estate: evidence from England. Journal of Urban Economics, 56(2), 192-216.

Merlo, A., Ortalo-Magne, F., and Rust, J. (2015). The home selling problem: Theory and evidence. International Economic Review, 56(2), 457-484.

Ngai, L. R., and Tenreyro, S. (2014). Hot and cold seasons in the housing market. American Economic Review, 104(12), 3991-4026.

Novy-Marx, R. (2009). Hot and cold markets. Real Estate Economics, 37(1), 1-22.

Salant, S. W. (1991). For sale by owner: When to use a broker and how to price the house. The Journal of Real Estate Finance and Economics, 4(2), 157-173.

Wheaton, W., and Nechayev, G. (2008). The 1998-2005 housing "bubble" and the current "correction": What's different this time?. Journal of Real Estate Research, 30(1), 1-26.

Yavas, A., and Yang, S. (1995). The strategic role of listing price in marketing real estate: theory and evidence. Real Estate Economics, 23(3), 347-368. 


\section{A Other Tables and Figures}

Table 3: Descriptive Statistics

\begin{tabular}{|c|c|c|c|c|c|c|}
\hline & \multicolumn{2}{|c|}{$\begin{array}{l}\text { Asking Price } \\
\left(€ / \mathrm{m}^{2}\right)\end{array}$} & \multicolumn{2}{|c|}{$\begin{array}{c}\text { Transaction Price } \\
\left(€ / \mathrm{m}^{2}\right)\end{array}$} & \multicolumn{2}{|c|}{$\begin{array}{l}\text { Price Discount } \\
\text { (in \%) }\end{array}$} \\
\hline & Mean & Std. Dev. & Mean & Std. Dev. & Mean & Std. Dev. \\
\hline Spain & 2139 & 516 & 1795 & 408 & 14.86 & 4.15 \\
\hline A Coruña & 1973 & 413 & 1562 & 303 & 18.93 & 3.69 \\
\hline Álava & 2118 & 360 & 1670 & 259 & 18.31 & 4.49 \\
\hline Albacete & 1348 & 279 & 1051 & 171 & 18.34 & 4.15 \\
\hline Alicante & 1328 & 212 & 1063 & 177 & 18.01 & 4.59 \\
\hline Almería & 1242 & 323 & 974 & 245 & 18.80 & 3.60 \\
\hline Asturias & 1729 & 285 & 1386 & 215 & 18.68 & 3.53 \\
\hline Ávila & 1123 & 222 & 939 & 222 & 12.50 & 6.21 \\
\hline Badajoz & 1276 & 252 & 998 & 193 & 19.74 & 4.63 \\
\hline Balears (Illes) & 1963 & 239 & 1581 & 240 & 17.31 & 9.04 \\
\hline Barcelona & 2709 & 632 & 2272 & 497 & 14.11 & 6.00 \\
\hline Burgos & 1653 & 413 & 1311 & 318 & 18.52 & 3.30 \\
\hline Cáceres & 1351 & 286 & 1046 & 247 & 21.41 & 6.81 \\
\hline Cádiz & 1750 & 619 & 1409 & 478 & 17.39 & 4.27 \\
\hline Cantabria & 2014 & 411 & 1628 & 321 & 17.16 & 3.77 \\
\hline Castellón & 1174 & 309 & 889 & 197 & 20.46 & 5.13 \\
\hline Ceuta & 2258 & 242 & 1927 & 260 & 14.85 & 5.07 \\
\hline Ciudad Real & 1199 & 361 & 967 & 310 & 15.91 & 4.43 \\
\hline Córdoba & 1450 & 296 & 1169 & 202 & 16.63 & 4.54 \\
\hline Cuenca & 1267 & 447 & 1014 & 275 & 16.88 & 7.13 \\
\hline Girona & 1935 & 328 & 1502 & 228 & 20.67 & 5.68 \\
\hline Granada & 1592 & 344 & 1235 & 203 & 18.99 & 5.51 \\
\hline Guadalajara & 1368 & 387 & 1125 & 324 & 15.81 & 4.82 \\
\hline Guipúzcoa & 3855 & 861 & 3083 & 526 & 16.89 & 4.46 \\
\hline Huelva & 1194 & 220 & 964 & 178 & 17.03 & 4.91 \\
\hline Huesca & 1486 & 259 & 1136 & 122 & 22.26 & 6.10 \\
\hline
\end{tabular}

Note: Asking and transaction prices in $€$ per square meter, price discount as percent of the asking price. Averages over the period $2010-2020$. 
Table 4: (Continued.) Descriptive Statistics

\begin{tabular}{|c|c|c|c|c|c|c|}
\hline & \multicolumn{2}{|c|}{$\begin{array}{l}\text { Asking Price } \\
\left(€ / \mathrm{m}^{2}\right)\end{array}$} & \multicolumn{2}{|c|}{$\begin{array}{c}\text { Transaction Price } \\
\left(€ / \mathrm{m}^{2}\right)\end{array}$} & \multicolumn{2}{|c|}{$\begin{array}{l}\text { Price Discount } \\
\text { (in } \%)\end{array}$} \\
\hline & Mean & Std. Dev. & Mean & Std. Dev. & Mean & Std. Dev. \\
\hline Jaén & 1357 & 390 & 1026 & 286 & 20.31 & 3.88 \\
\hline La Rioja & 1415 & 346 & 1086 & 269 & 19.96 & 5.18 \\
\hline Las Palmas & 1643 & 277 & 1362 & 217 & 14.27 & 4.53 \\
\hline León & 1480 & 320 & 1100 & 218 & 22.78 & 4.67 \\
\hline Lleida & 1193 & 347 & 907 & 274 & 21.65 & 3.75 \\
\hline Lugo & 1554 & 325 & 1188 & 239 & 20.53 & 3.37 \\
\hline Madrid & 2605 & 542 & 2316 & 459 & 9.88 & 5.22 \\
\hline Málaga & 1714 & 205 & 1404 & 169 & 16.07 & 5.23 \\
\hline Melilla & 1776 & 127 & 1573 & 134 & 11.57 & 8.57 \\
\hline Murcia & 1338 & 421 & 969 & 254 & 23.07 & 5.33 \\
\hline Navarra & 1971 & 455 & 1587 & 302 & 16.22 & 4.98 \\
\hline Ourense & 1725 & 364 & 1203 & 182 & 25.44 & 5.06 \\
\hline Palencia & 1481 & 259 & 1108 & 182 & 22.42 & 4.67 \\
\hline Pontevedra & 1805 & 191 & 1398 & 111 & 19.16 & 5.31 \\
\hline Salamanca & 1796 & 354 & 1395 & 237 & 20.51 & 4.89 \\
\hline Santa Cruz de Tenerife & 1591 & 348 & 1338 & 269 & 13.52 & 3.76 \\
\hline Segovia & 1568 & 358 & 1275 & 255 & 15.53 & 4.13 \\
\hline Sevilla & 1799 & 395 & 1498 & 289 & 14.43 & 3.94 \\
\hline Soria & 1441 & 389 & 1143 & 333 & 19.25 & 4.03 \\
\hline Tarragona & 1570 & 401 & 1246 & 352 & 17.80 & 5.74 \\
\hline Teruel & 1414 & 323 & 1166 & 331 & 19.99 & 12.01 \\
\hline Toledo & 1273 & 511 & 1057 & 486 & 16.39 & 4.21 \\
\hline València & 1508 & 448 & 1175 & 289 & 18.22 & 5.81 \\
\hline Valladolid & 1505 & 368 & 1194 & 312 & 18.55 & 3.77 \\
\hline Vizcaya & 2916 & 485 & 2457 & 440 & 14.96 & 3.19 \\
\hline Zamora & 1355 & 278 & 1029 & 190 & 19.64 & 4.76 \\
\hline Zaragoza & 1637 & 452 & 1305 & 373 & 17.99 & 4.27 \\
\hline
\end{tabular}

Note: Asking and transaction prices in $€$ per square meter, price discount as percent of the asking price. Averages over the period $2010-2020$. 